Joanna Lisek

\title{
„Wszystkich zabrali. Zostałam Samajedna. Bez nikogo”. Dziennik intymny Fryderyki Brück ze Stanisławowa ${ }^{1}$
}

Na pierwszej stronie cudem ocalałego z pożogi zeszyciku formatu A6 widnieje napis: „Pamiętnik. Fryderyka Brück. 1941”. Trzydzieści dziewięć pożółkłych stroniczek zapisanych drobnym atramentowym pismem, przechowywanych z pietyzmem w rodzinie państwa Hermanów, czekało prawie siedemdziesiąt lat na moment, gdy uwiecznione na nich zdarzenia i uczucia będą mogły dla szerszego grona czytelników stać się świadectwem życia i Zagłady Żydów ze Stanisławowa.

Zapiski obejmują okres od 7 maja 1941 do 1 sierpnia 1942 r. Początkowo prowadzone były regularnie, z dużą systematycznością, później pojawiły się nawet dwutygodniowe przerwy, a to, co się w tym czasie zdarzyło, opisane jest w jednym fragmencie. Tragedia utraty przez Fryderykę całej rodziny spowodowała najdłuższą czteromiesięczną przerwę, poprzedzającą ostatni wpis. Uwzględniając okoliczności historyczne, w jakie uwikłana została autorka oraz jej przemiany wewnętrzne, dziennik można podzielić na siedem etapów:

\section{Okres od 7 V 1941 do 22 VI 1941}

Zapiski koncentrują się na perypetiach uczuciowych autorki. Ich głównym tematem jest jej związek z Miśkiem Bacherem, który trwa od trzech miesięcy. Wcześniej jej chłopakiem był Zbyszek, który 8 V 1941 odszedł do wojska. Życie w tym czasie toczy się spokojnie - dziewczyna uczy się, chodzi na spacery, potańcówki.

\section{Okres od 22 VI 1941 do 3 VIII 1941}

Sytuacja zmienia się diametralnie po wybuchu wojny niemiecko-sowieckiej. Fryderyka opisuje panikę i ruch w mieście. Kończą się spacery i zabawy. Dziadkowie przenoszą się do domu jej rodziców, ponieważ niedaleko ich miejsca zamieszkania spadła bomba.

\footnotetext{
${ }^{1}$ Dziękuję panu Januszowi Hermanowi za przekazanie mi dziennika Fryderyki Brück do opracowania i publikacji. Dziennik ten wraz z informacją, że jego autorka zginęła, otrzymał od swojego ojca Zdzisława, który mieszkał w Stanisławowie. Żadne inne szczegóły dotyczące okoliczności odnalezienia zapisków Fryderyki nie są znane, a pan Zdzisław Herman już nie żyje.
} 


\section{Okres od 10 VII 1941 do 31 VII 1941}

Do Stanisławowa wkracza armia węgierska, nastaje „spokój, ład i porządek”. Od 15 lipca autorka pracuje w kahale.

\section{Okres od 3 VIII 1941 do 11 X 1941}

Gestapo przejmuje administrację w Stanisławowie. 3 sierpnia ojcowie Fryderyki i Miśka zostają internowani; nigdy już nie wrócą. W obliczu tych nieszczęść umacnia się związek z Miśkiem. 10 września Fryderyka obchodzi urodziny. Pomaga Miśkowi załatwić zaświadczenie o pracy, a potem posadę przy wydawaniu chleba. 22 września to początek Nowego Roku żydowskiego. 3 października stwierdza, że „sprawa Getta jest przesądzona”. Ma problemy z załatwieniem dla siebie pracy, w końcu dostaje posadę w Winterhilf.

\section{Okres od 11 X 1941 do 21 XI 1941}

11 października zostaje przez autorkę nazwany Dniem Pogromu. Żydzi są zabierani z domów, przychodzą też po Brücków. Fryderyka pertraktuje z Niemcem i ocala rodzinę. Rano dowiaduje się, że Żydów spędzono na cmentarz i wystrzelano. Fryderyka bardzo martwi się o Miśka, myśląc, że on już nie żyje: „Ja chciałam skoczyć z 3 piętra, bo zrozumiałam, że życie moje bez Miśka jest niczem”. 13 października dziewczyna spotyka się jednak ze swoim chłopakiem, któremu udało się wrócić z cmentarza: „On już był w grobie, ale go zwolnili. Dużo ludzi z cmentarza nie wróciło i nie ma już ich pośród żyjących" - wymienia znajomych i bliskich, którzy zginęli. Pierwsza połowa listopada upływa na szukaniu mieszkania na terenie przyszłego getta.

\section{Okres od 21 XI 1941 do 20 III 1942}

Od 21 listopada rodzina autorki mieszka w getcie. Pierwsze dni po przeprowadzce spędza głównie z Miśkiem: „Złączeni jednym słowem, jedną myślą Kocham”. 17 grudnia omal nie dochodzi do zbliżenia między nimi. Jeden z wpisów obejmuje czas całego miesiąca - stycznia. W tym okresie Fryderyka, w czasie choroby Miśka, zaczęła się spotykać z drugim chłopcem - Iziem Waksm[anem?]. Miśko dowiaduje się o tym, ale w końcu się godzą, a Izio przestaje przychodzić do Fryderyki. 11 lutego autorka rozpamiętuje, że mija pierwsza rocznica zerwania ze Zbyszkiem. 13 lutego wspomina, że minął już rok od pierwszego spaceru z Miśkiem, który był początkiem ich wzajemnej fascynacji. W połowie lutego choruje na grypę, a miesiąc później leży w domu z atakiem ślepej kiszki lub zapaleniem jajnika.

\section{Okres od 31 III do 1 VIII 1942}

Fryderyka opisuje pokrótce, co wydarzyło się w tym czasie. 31 III miała miejsce „akcja na żebraków”. Zaczęto wywozić Żydów, ona była u Miśka i nie puszczono jej do domu. Kiedy wróciła rano do siebie - nikogo już nie zastała. Zamieszkała 
z ciocią Rózią. Flirtuje z wieloma mężczyznami. Cały czas jednak spotyka się z Miśkiem. Od 1 sierpnia prowadzi własne gospodarstwo - tak zdecydowała jej ciotka.

Tu pamiętnik urywa się.

\section{Autorka}

Czego można dowiedzieć się o autorce na podstawie jej dziennika, a także materiałów źródłowych oraz opracowań dotyczących historii miasta Stanisławowa i społeczności żydowskiej licznie je zamieszkującej²? Fryderyka była córką lekarza dentysty Ludwika Brücka. Mieszkała przy ulicy Sobieskiego $11^{3}$, w kamienicy należącej do jej ojca, naprzeciw eleganckiego hotelu „Warszawa”. Perla Brück, prawdopodobnie jej babka, była właścicielką kamienicy przy ul. Gołuchowskiego 9.

Fryderyka należała więc do zamożnej elity żydowskiej. Świadczy o tym także opis przenosin rodziny na teren getta: Brückowie byli w stanie zapłacić sporą sumę za wynajem dość dobrego mieszkania. Ubodzy Żydzi przeprowadzali się w ostatniej chwili, mieszkali często w prowizorycznych lokalach, ogromnie stłoczeni. Potwierdzeniem przynależności do elity jest fakt aresztowania ojca wraz z grupą przedstawicieli inteligencji polskiej i żydowskiej zatrzymanej i straconej wkrótce po przejęciu administracji miasta przez Niemców (koniec lipca 1941 r.). Ojciec Fryderyki został internowany 3 sierpnia. Pozycja społeczna ojca dawała Fryderyce poczucie pewności siebie i przekonanie o konieczności uprzywilejowanego traktowania przez okupantów jej rodziny. Przejawia

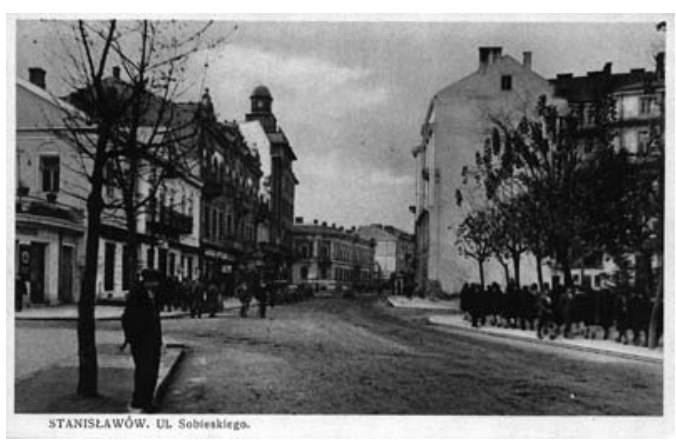

Widok na ul. Sobieskiego; w głębi hotel Warszawa, naprzeciwko którego mieszkała Fryderyka. Ze zbiorów ilustracji biblioteki Instytutu Ludoznawstwa NANU (Narodowej Akademii Nauk Ukrainy) nr ew. 23684 się to w krytycznym momencie, określanym przez Fryderykę jako Dzień Pogromu, gdy Niemcy spędzając Żydów na cmentarz, przyszli także po jej rodzinę. Po opuszczeniu mieszkania i zejściu na dół Fryderyka podeszła przed domem do jednego z Niemców i powiedziała mu, że jest córką lekarza dentysty. „Na tej podstawie - pisze - zwolnił mnie” - a także innych członków rodziny. Z lektury dziennika można także wynieść wrażenie, że rodzina Brück znała osobiście przedstawicieli Judenratu, np. Izraela i Henia Seibaldów (Izrael był przewodniczącym Judenratu do 12 X 1941 r.). Dzięki tym znajomościom

${ }^{2}$ W 1931 r. w Stanisławowie mieszkało 24823 Żydów, co stanowiło 41,4 \% mieszkańców.

${ }^{3}$ Za informacje o stanie posiadania rodziny Brück, uzyskane na podstawie spisu właścicieli budynków w Stanisławowie, dziękuję panu Rajmundowi Piżanowskiemu. 
Fryderyka załatwiła najpierw zaświadczenie o pracy, a potem także posadę swojemu chłopakowi, Miśkowi Bacherowi. Nie bez znaczenia jest też fakt, że w czasie okupacji armii węgierskiej (lipiec 1941) autorka dziennika pracuje w kahale.

Wiek Fryderyki możemy ustalić w przybliżeniu dzięki informacji zapisanej $\mathrm{w}$ dzienniku na temat zdawania przez nią egzaminów czeladniczych w czerwcu 1941 r. Zgodnie z ówczesnym systemem edukacyjnym ${ }^{4}$ mogła mieć wtedy 19-20 lat. Z opisu dnia urodzin wiemy, że przyszła na świat 10 IX. W momencie, gdy zaczyna się dziennik, autorka jest osobą pełnoletnią, uczy się i jest na utrzymaniu rodziców, z którymi mieszka.

Identyfikację narodowo-religijną rodziny Fryderyki możemy określić jako polsko-żydowską. Nie ma wątpliwości, że polski był pierwszym językiem autorki dziennika; jej polszczyzna nie ma naleciałości jidyszowych. Ani jej imię, ani ojca (Ludwik) nie są imionami żydowskimi. Natomiast imię babki - Perla - jest typowo żydowskie. Można więc przypuszczać, że Fryderyka należy do drugiego pokolenia rodziny Brück ulegającego asymilacji. Obraca się jednak w środowisku żydowskim, większość jej znajomych trafia do getta, nie wspomina też w ogóle o kimś, kto zostałby po aryjskiej stronie. Lektura dziennika nie sprawia wrażenia, jakoby autorka miała jakieś problemy identyfikacyjne; nie czuje się na tyle Polką, by zamknięcie jej w getcie naruszało jej poczucie tożsamości. Można przyjąć, że jest typową przedstawicielką szerokiego wówczas kręgu Żydów galicyjskich mocno osadzonych w kulturze polskiej, zeświecczonych, ale nieodcinających się od judaizmu, zasymilowanych, częściowo zintegrowanych, ale w życiu codziennym obracających się głównie we własnym gronie ${ }^{5}$.

Lektura dziennika przekonuje nas poza tym o daleko posuniętym procesie sekularyzacji w rodzinie Brücków. W prowadzonych przez ponad rok zapiskach tylko raz pojawia się wzmianka o żydowskim święcie - gdy Fryderyka w czasie Rosz ha-Szana, żydowskiego Nowego Roku, szczególnie dotkliwie odczuwa brak ojca. „Pierwszy dzień Nowego Roku ${ }^{6}$. Niestety bez ojca. Nastrój w domu fatalny”. Ani razu w tekście nie pojawia się słowo „szabat” czy „synagoga”, nie ma żadnych odniesień do zasad religii żydowskiej, a słowo Żyd pada tylko raz w opisie tragicznych wydarzeń na cmentarzu przy ulicy Sapieżyńskiej, gdy Niemcy zamordowali 10 tys. Żydów. Nie znaczy to jednak, że Fryderyka jest ateistką. Bóg pojawia się na stronach dziennika nie tylko jako adresat zawołań „O Boże!”, które można by potraktować jako zakorzenione w języku, pozbawione treści wykrzykniki. W sytuacji wielkiego zagrożenia, w dniu masakry 12 X 1941 r., Fryderyka modli się o ocalenie swego przyjaciela: „I tak bardzo prosiłam Boga, aby on żył, abym go mogła jeszcze

${ }^{4}$ Por. Ustawa o ustroju szkolnictwa z dnia 11 marca 1932 r., Warszawa 1933; http://www. dbc.wroc.pl/dlibra/doccontent?id=2663\&dirids=1.

${ }^{5}$ Por. E. Mendelsohn, Żydzi Europy Środkowo-Wschodniej w okresie międzywojennym, przeł. A. Tomaszewska, Warszawa 1992.

${ }^{6}$ Święto Nowego Roku - Rosz ha-Szana, obchodzone pierwszego i drugiego dnia miesiąca tiszri (wrzesień - październik); zgodnie z tradycją Bóg osądza wówczas postępowanie ludzi i zapisuje ich imiona do Księgi Życia lub Księgi Śmierci. 
zobaczyć i przycisnąć, i ucałować”, a gdy dowiaduje się, że Miśko przeżył, na stronach dziennika zwraca się bezpośrednio do Stwórcy: „O Boże! Nie wiem jak mam Ci dziękować, że[ś] zostawił nas oboje przy życiu, że jesteśmy razem”.

Treść zapisków świadczy, że ich autorka nie ma wyraźnych poglądów politycznych. Brak jest śladów utożsamiania się przez nią z syjonizmem, popularnym przed wojną w kręgach młodzieży żydowskiej ${ }^{7}$, bądź też z socjalizmem czy komunizmem.

Fryderyka ukończyła szkołę rzemieślniczą. Znała niemiecki, co w pewnym momencie uratowało jej życie. Na pewno nie stanowiła przykładu osoby - jakich wiele było wśród młodzieży żydowskiej - o rozbudzonych aspiracjach, która godząc zdobywanie wykształcenia z pracą zarobkową, cały swój wolny czas spędzałaby w bibliotekach, na wykładach popołudniowych czy imprezach kulturalnych, upatrując w samokształceniu jedyną drogą awansu społecznego ${ }^{8}$. Status materialny rodziny Brück z pewnością gwarantował jej warunki do edukacji, z których ona widocznie nie chciała skorzystać. Nie była też osobą szczególnie oczytaną, w jej notatkach nie ma odniesień do jakichkolwiek lektur, ale jej polszczyzna jest niemal bezbłędna: pisze poprawnie zarówno pod względem ortograficznym, jak i stylistycznym.

Fryderyka nie ma z pewnością cech rewolucjonistki, nie walczy o ideały narodowe, nie jest zaangażowana w życie religijne, ale też nie sprzeciwia się jego przejawom. Nie wyróżnia się erudycją ani refleksyjnym stosunkiem do życia. Nie ma w niej odruchów buntu przeciw rodzicom, na kartkach jej dziennika nie znajdziemy śladów konfliktu pokoleń, o rodzicach pisze z szacunkiem i czułością: matka to zawsze Mamcia, ojciec - Tatko. Mimo silnego egocentryzmu nie wydaje się, aby Fryderyka miała poczucie wyjątkowości własnego losu czy unikalności momentu historycznego, w którym przyszło jej żyć.

\section{Miłość, namiętność - życie emocjonalne}

Co wobec tego zaprząta jej głowę, co popycha do chwycenia za pióro i sporządzania notatek? Osią tej aktywności jest życie emocjonalne - perypetie miłosne i doznania seksualne. Fryderyka przelewa na papier przede wszystkim szeroki wachlarz emocji - od euforycznej radości, miłości, pożądania, przez niepokój, strach, złość, wściekłość, aż do rozpaczy i zobojętnienia. Potwierdzają to opisy własnych stanów emocjonalnych, które pojawiają się w dzienniku; Fryderyka pisze o sobie, że jest „zdenerwowana”, „załamana”, „przygnębiona”, „zgorzkniała”, „rozdrażniona”, „wściekła”, „bardzo zła”, „nachmurzona”, „sparaliżowana”, „szczęśliwa”, lub też: „serce mi się ścisnęło”, „strach mnie ogarnia”, „czuję się znakomicie”, „jest cudnie”, „jest mi ciepło, wesoło”, „było mi tak błogo”, „było bardzo przyjemnie”, „było pięknie”.

\footnotetext{
${ }^{7}$ Por. Ostatnie pokolenie. Autobiografia polskiej młodzieży żydowskiej okresu międzywojennego ze zbiorów YIVO Institute for Yewish Research w Nowym Jorku, oprac. A. Cała, Warszawa 2003.

${ }^{8} \mathrm{O}$ takim modelu dojrzewania zob.: J. Lisek: Jung Wilne - żydowska grupa artystyczna, Wrocław 2005.
} 
Od 20 VI 1941 zaczyna stosować system symboli oznaczających emocjonalne nacechowanie przedstawionych wydarzeń. Początkowo są to plusy $(+)$, potem plusy i wykrzykniki (!), aż wreszcie plusy, wykrzykniki oraz minusy: małe (-) i duże $(-)$. Pierwsze postawienie plusów pojawia się w dniu, gdy dochodzi do gorących pieszczot między nią a Miśkiem. Wykrzykniki sygnalizujące ważkość daty zaczyna stosować począwszy od dnia swoich urodzin. Minus pojawia się po raz pierwszy w Rosz ha-Szana 1941 r., kiedy Fryderyka dotkliwie odczuwa brak ojca zabranego przez gestapo, smutno jej, że Miśko nie może być przy niej w tym dniu, a dodatkowo docierają do niej co chwilę „wiadomości wywołujące płacz” (Fryderyka zwykle nie przytacza krążących po mieście nowin czy - jak to nieraz sama określa - plotek). Tego dnia pisze: „Siedziałam sama w domu, myślałam i płakałam” (22 IX 1941). Oznaczenia te stanowią czasem istotne dopełnienie tekstu, swoiste emocjonalne podsumowanie dnia. Charakterystyczne jest to, że znaki te nie wykluczają się wzajemnie, zwykle przy ważnych dniach pojawiają się obok siebie plusy, minusy i wykrzykniki. Pokazuje to istotną cechę osobowości Fryderyki, która nawet w najgorszych chwilach stara się znaleźć pozytywne aspekty danej sytuacji. Często targają nią uczucia sprzeczne.

Emocjonalnie nacechowane są także chętnie stosowane przez nią zdrobnienia. Szczególnie często pojawiają się spieszczeniach imion: Izio, Miśko, Nusio, Tina, Dunio, Henio9. O członkach rodziny pisze Mamcia, Tatko, Dziadzio, ciocia, a swojego chłopaka nazywa Dzióbaskiem, Misieńkiem. Używa także określeń „słoneczko” czy „pociumać”.

Większość przedstawionych zdarzeń ukazana jest w perspektywie wzlotów i upadków jej związku z Miśkiem. Początkowo Fryderyka jawi się jako beztroska uczennica szykująca się do egzaminów, która chodzi na potańcówki, czasem pije alkohol i pali papierosy, a najważniejszym problemem dnia jest to, z kim pójdzie na spacer. Uważa, że Miśko poświęca jej zbyt mało uwagi („woli na Lipowej parkan podpierać”, 14 V 1941). Ona natomiast „kocha bezgranicznie i poza nim nie ma nikogo” (14 V 1941). Związek ten nabiera zażyłości wobec sytuacji rosnącego zagrożenia i tragizmu wydarzeń po wybuchu wojny niemiecko-sowieckiej. Młodzi niemal każdego dnia spotykają się i szukają okazji do pieszczot. Dlatego w zapiskach Fryderyki odnajdujemy dwubiegunowość: z jednej strony - po zabraniu obydwu ojców, jej i Miśka, przez gestapo - pisze, że „już nie mamy sił do życia ani do płaczu”, ale jednocześnie pod tą samą datą zaznacza, że jest cudownie, bo całe popołudnie pieszczą się z Miśkiem i marzą o wspólnej przyszłości (3 VIII - 3 IX 1941). W dniu swoich urodzin notuje, że był on „bardzo smutny, bowiem nie ma mego tatka”, jednocześnie jednak kończy opis słowami: „Miśko był w dobrym humorze i bardzo czuły. Taki był kochany, taki słodki. Dzień ten cudnie minął i bardzo przyjemnie” (10 IX 1941). Ta ambiwalencja osiąga kulminację po tragicznych wydarzeniach na

${ }^{9}$ Spieszczenia imion i zdrobnienia to typowa cecha polszczyzny kresowej; zob. np. E. Dzięgiel, Polska gwara wsi Zielonej na Podolu na tle innych gwar potudniowokresowych. Fleksja imienna i werbalna, Kraków 2001. 
cmentarzu, kiedy ginie wielu znajomych Fryderyki, a Miśko, choć jest zabrany na miejsce egzekucji, uchodzi z życiem. Zanim jednak Fryderyka się o tym przekona i sądzi, że ukochany jest w gronie zabitych, pojawia się myśl o samobójstwie.

Kiedy ogólna sytuacja w mieście staje się bardzo napięta, każda nieobecność Fryderyki w domu budzi niepokój jej rodziny. Tymczasem młodzi znajdują azyl we wzajemnej bliskości: „Jest nam ze sobą tak dobrze. [...] Gdy mam go obok siebie jestem zupełnie inna, jest mi ciepło, wesoło i tak dobrze jak z nikim” (24 X 1941). Dlatego Fryderyka dostrzega nawet pozytywny dla niej wpływ traumatycznych doświadczeń Miśka, który stanął oko w oko ze śmiercią: „Teraz dopiero Miśko zrozumiał, czem byłam dla niego i nauczył się mię odpowiednio traktować” (24 X 1941). Ona też dochodzi do wniosku, że nawet się nie spodziewała, jak Miśko będzie jej „niewolniczo potrzebny” (13 IX 1941). Ich relacja ma burzliwy charakter - czasami się kłócą, obrażają, nieraz Fryderyka ma mu ochotę dać po głowie, jednak myślą o zaręczynach, a w pewnym momencie o ślubie; początkowo szukają na terenie getta wspólnego mieszkania, ale w końcu nie udaje im się zamieszkać razem. Autorka dziennika walczy o bezpieczeństwo Miśka, załatwiając mu zaświadczenie o pracy i znajdując posadę. W nowej, brutalnej rzeczywistości przyjmuje postawę aktywną - potrafi zrobić straszną awanturę w Judenracie (3 X 1941), pertraktuje z Niemcem, aby cała jej rodzina uniknęła wywózki na cmentarz. Jednak w głębi duszy aż do pewnego momentu pozostaje romantyczną dziewczyną, oczekującą celebrowania miłosnego związku. W całej tej zawierusze wojennej ona wciąż odlicza dni spędzone wspólnie z Miśkiem, pamięta o rocznicy pierwszego z nim spaceru, który dał początek ich wzajemnej fascynacji. Oczekuje, że on też będzie o tym pamiętał: „Ja jestem bardzo romantyczna natura i tak bardzo zależało mi na tym, aby Miśko pamiętał o tym dniu, lecz niestety zapomniał. W pierwszej chwili byłam bardzo zła, ale potem zrozumiałam, że dziś o ważniejszych rzeczach zapomina się" (13 II 1942). Przy pobieżnej lekturze dziennika może się wydać, że Fryderyka nie ma poczucia zagrożenia, które czyha na nią i na jej chłopca, jest to jednak błędne wrażenie - ona ma świadomość zewsząd czającej się śmierci, bo kiedy jest szczęśliwa, to dlatego, że: „pozwolił nam Pan Bóg ten dzień dożyć [podkreśl. moje - J. L.] i razem go spędzić”. Fizyczna bliskość daje im „zapomnienie o całym świecie” (7 IX 1941), stanowi ucieczkę od „dnia codziennego i jego zmartwień” (3 VIII - 3 IX 1941).

Fryderyka szuka języka, którym mogłaby opisywać ich przeżycia intymne, określa je jako: „duszenie”, „ciumanie”, „pieszczenie”, „całowanie”, „kąsanie”, „grzanie się”. Fascynuje ją obserwowanie rosnącego podniecenia u mężczyzny: „Miśko rozpalił się od razu, sapał i pieścił mnie” (4 X 1941), „okropnie rozpalił, wprost był nie do poznania. Cały czerwony, oczy mu się świeciły jak u złodzieja” (17 XII 1941). Pisze też o swoich doznaniach „Pieściliśmy się tak mocno, na całego. Było mi tak błogo, że nie mogłam usiedzieć” (17 XII 1941). Fryderyka jest dziewicą i przez rok chodzenia z Miśkiem nie chce rozpocząć współżycia, choć czasami niewiele brakuje, aby doszło do zbliżenia. „Rozpaliliśmy się tak do siebie, że gdybym była tam dłużej siedziała, byłabym mu się oddała i byłoby przepadło” (17 XII 1941), „O mały włos byłoby po wszystkim, ale opanowaliśmy się. Miałam tak nerwy naprężone, że cały wieczór 
byłam jak pijana” (1 II - 5 II 1942). Z początkiem roku 1942 ma przelotny romans z Iziem Waksm[anem] - kobieciarzem, który jednak zraża ją do siebie niestałością i brakiem zainteresowania prawdziwym związkiem, więc choć Miśko dowiaduje się o wszystkim - godzą się i znów „[j]est cudnie. Kochamy się” (1 II - 5 II 1942).

Sytuacja zmienia się diametralnie, kiedy Niemcy 31 III 1942 r. zabierają całą rodzinę Brücków i Fryderyka zostaje sama: „Zostałam Samajedna. Bez nikogo” (31 III - VII 1942). W tym czasie następuje najdłuższa przerwa w jej zapiskach, a później pośpiesznie, niestarannie zrobiony ostatni wpis chaotycznie relacjonujący zdarzenia ostatnich czterech miesięcy. Pośród wyliczenia osób, których już nie ma, odnajdujemy skreślone w paru zdaniach dalsze losy związku Fryderyki z Miśkiem. Ona spotyka się z wieloma mężczyznami: Aboschem, Zahlerem, Karpenem, Pietrusi (?), lecz jednocześnie pisze: „Z Miśkiem żyję bardzo dobrze, kochamy się”. Chce współżyć z Zahlerem, ale wpierw postanawia stracić dziewictwo z Miśkiem (przypuszczalnie po to, żeby się nie zorientował, że go zdradza): „Miśkowi nie chciałam się oddać, ale teraz chcę być Zahlera więc muszę się oddać Miśkowi”. Kiedy się na to decyduje, Miśko nie może temu sprostać, co doprowadza ją do takiej wściekłości, że - jak pisze - przez dwa dni choruje. Miśko bardzo się tym martwił, szukał powodu tego niepowodzenia: „albo nie ma do mnie pociąu płciowego, albo to dowód wyczerpania fizycznego”. Zaraz po tym zdaniu Fryderyka pisze: „Z Zahlerem jest cudnie. W domu ciężko - Mamci brakuje na każdym kroku” (3 III - VII 1942).

Z tego ostatniego fragmentu wyłania się obraz dziewczyny, której osobowość uległa destrukcji. Jest zagubiona, miota się między mężczyznami, a jednocześnie narasta w niej poczucie samotności, pogłębiane ubywaniem bliskich i znajomych z jej otoczenia. Ludzie znikają, można wrócić do domu i nie zastać nikogo, więc i azyl z Miśkiem jest niepewny. Fryderyka spotyka zatem mężczyzn i w pośpiechu, jakby na zapas, wchodzi z nimi w przelotne relacje - „z nim się motałam”, „z nim też coś miałam”, „on się do mnie pali”. Gra z mężczyznami pozwala jeszcze raz napisać: ,jest cudnie”. Pożądanie, które wzbudza, daje jej poczucie władzy: „przynosi papierosy i chce coś za to, lecz ja się nie spieszę" - tak brzmi zdanie, które zamyka dziennik.

Ten ostatni fragment, złożony z krótkich zdań wyrzucanych jakby w zadyszce, wydaje się zapisem wyścigu ze śmiercią, której oddech pochłania wszystko dookoła. W rozpalonych zmysłach Fryderyka znajduje życie, nie może już chronić swego dziewictwa, nie ma już na to czasu, chce zaznać rozkoszy do końca...

\section{Fakty}

Te osobiste losy wikłają się w zdarzenia, które później zostaną uznane za historyczne i złożą się na epilog dziejów Żydów w Stanisławowie. Co wynika z konfrontacji dziennika Fryderyki z wydarzeniami lat 1941-1942? Autorka przywołuje wszystkie przełomowe momenty tego okresu - poczynając od wybuchu wojny sowiecko-niemieckiej, którą traktuje jako drugą w swoim życiu. Ta wrześniowa wojna nie budzi w niej przerażających wspomnień, kojarzy jej się przede wszystkim z nudą: „O Boże! jak to źle tak siedzieć na wojnie i nie mieć kogoś bliskiego przy 
sobie. Podczas tamtej wojny miałam obok siebie stale Zbyszka, to nie byłam taka samotna, a teraz, aż strach mię ogarnia jak pomyślę, że znów nastanie dzień taki strasznie ponury i nudny" (26 VI 1941).

Choć nie opisuje pogromu żydowskiego, jaki miał miejsce w Stanisławowie po opuszczeniu miasta przez Rosjan, to krótką okupację wojsk węgierskich w lipcu 1941 r. wita jakby z ulgą: „Wkroczenie armii węgierskiej. Spokój, ład i porządek" (10 VII 1942). W tym momencie wojna nie budzi jeszcze we Fryderyce grozy i przerażenia. Ich dom odwiedza często kapitan węgierski (55-letni) - przynosi im słodycze i papierosy, obcałowuje jej rączki, Fryderyka przypuszcza, że się w niej zakochał, i pisze: „Jest cudownie. On stary, ja skrycie śmieję się z niego, a przy nim słodko się uśmiecham. I tak mam przygodę wojenną" (15 VII - 31 VII 1941). O przyjaznym stosunku żołnierzy węgierskich do ludności Stanisławowa czytamy też w relacji Czesława Hermana: „Byli bardzo przyjaźnie ustosunkowani do Polaków - udzielali pomocy żywnościowej, żołnierze węgierscy odwiedzali domy zamieszkałe przez mieszkańców polskich. Stosunek żołnierzy garnizonu węgierskiego nie był też negatywny wobec pozostałych mieszkańców Stanisławowa pochodzenia żydowskiego i ukraińskiego"10.

Autorka opisuje pierwszą akcję nazistowską przeciwko Żydom i Polakom w Stanisławowie, kiedy wraz z innymi przedstawicielami inteligencji aresztowany zostaje jej ojciec. Źródła podają, że rodziny zatrzymanych wówczas osób utrzymywano w wierze, że ich bliscy żyją - mogli przynosić im paczki, łudzeni byli pogłoskami o mających nastapić zwolnieniach. Relacja Fryderyki w pełni to potwierdza - dziewczyna do końca dziennika wierzy, że jej tato żyje. Co pewien czas pogłoski zasłyszane w mieście dają jej nadzieję: „Ogólnie mówią w mieście, że jutro wypuszczą internowanych. Daj Boże!” (1 XI 1941). Jednak potem przychodzi rozczarowanie: „Ojca ciągle nie ma w domu. Plotki, z których nic nie jest prawdą” (2 XI 1941). Fryderyka nie wspomina o wprowadzonym we wrześniu 1941 r. obowiązku noszenia przez Żydów opaski z gwiazdą Dawida, ale też w jej dzienniku w ogóle nie pojawiają się opisy ubrania, ani własnego, ani cudzego. Także przed wybuchem wojny niemieckosowieckiej nie wspomina ani słowem, jak się ubiera np. na potańcówkę czy randkę; ten temat w ogóle w jej zapiskach nie istnieje. Jeżeli pojawia się opis wyglądu, to tylko w odniesieniu do Miśka i zmian na jego twarzy w chwilach bliskości fizycznej.

Fryderyka relacjonuje krwawą masakrę dokonaną na Żydach na cmentarzu przy ul. Sapieżyńskiej. Tutaj jednak pojawia się pewna rozbieżność w porównaniu z opracowaniami dotyczącymi zagłady Żydów w Stanisławowie ${ }^{11}$. Mianowicie na podstawie wielu relacji przyjmuje się, że wymordowanie 10 tys. Żydów na cmentarzu nastąpiło 12 X 1941, Fryderyka zaś opisuje Dzień Pogromu pod datą 11 X 1941.

${ }^{10}$ Zeznanie przed Komisją Ścigania Zbrodni przeciwko Narodowi Polskiemu w Łodzi (PP 19/02), za: http://stanislawow.net/wspomnienia/herman_droga.htm.

${ }^{11}$ Por.: Stanistawów [w:] The Encyclopedia of the Holocaust, red. I. Gutman, New York 1990; T. Berenstein, Eksterminacja ludności żydowskiej w dystrykcie Galicja (1941-1943), „Biuletyn ŻIH” 1967, nr 61, s. 3-58. 
Co więcej, ponieważ jest to dla niej szczególnie tragiczny, straszny dzień, jedyny raz w całym dzienniku pod notatką $\mathrm{z}$ tego dnia wpisuje jeszcze raz dużymi cyframi datę 11 X i podkreśla ją. Następne wpisy kolejno wypadają 12 i 13 X. Możliwe, że te trzy krytyczne dni zostały opisane 14 X, kiedy wiadomo już było, kto przeżył, kto zginął, a sytuacja się uspokoiła; daty mogły się jej wówczas pomylić. Opis wydarzeń na cmentarzu 12 X 1941 r. znajdujemy w zeznaniach Czesława Hermana przed Komisją Ścigania Zbrodni przeciwko Narodowi Polskiemu w Łodzi (PP 19/02). Trzeba je tu przytoczyć: „Zeznaję: widziałem w ową niedzielę jak ustawionych na ulicy Belwederskiej Żydów - kobiety, dzieci, mężczyzn (według mnie było ich tysiące) Gestapowcy, Schuzpolicjanci i policjanci ukraińscy bili nahajkami, kolbami karabinów oraz laskami, które wcześniej zabierali starcom żydowskim. Było to coś strasznego, walili na oślep, nie patrzyli na wiek, płeć, czy też w jaką część ciała biją. Widziałem jak Żydom pękały kości czaszki, krew zalewała twarze. [...] Obserwując to zdarzenie na Belwederskiej, słyszałem już masowe strzały dochodzące do mnie od strony zachodniej, z kierunku cmentarza żydowskiego, położonego nad Bystrzycą w odległości ok. 4 km na zachód od ul. Belwederskiej. Była to kanonada strzałów trwająca do zapadnięcia zmroku. [...] Co dokładnie działo się na cmentarzu dowiedziałem się dopiero wieczorem od Żydów zamieszkałych w naszym budynku [...]. W drodze do cmentarza przez cały czas ich bito, po czym na siłę wciskano ich w bramę cmentarną, do tego stopnia, że się dusili i matki trzymające małe dzieci nie mogły uchronić je przed zaduszeniem. Na terenie cmentarza były wykopane rowy. Gestapowcy, Schuzpolicjanci i policjanci ukraińscy kolejnym partiom Żydów kazali się rozbierać do naga, stawać przy rowach i strzelali do nich z karabinów maszynowych. [...] Były to dantejskie sceny. [...] Z opowiadań jednego z Żydów, który ocalał szczęśliwie z tej egzekucji, bo nie został trafiony kulą, wiem, że do wykopanych dołów trafiali ludzie żywi. Właśnie ten Żyd już po zakończeniu egzekucji w nocy, gdy cmentarz opustoszał, wydobył się spod trupów i wrócił do swojego domu”12. Chłopak Fryderyki, Miśko, był wśród ludzi zapędzonych na cmentarz, ale został zwolniony; Fryderyka pisze nawet: „On już był w grobie” (13 X 1941), co w świetle przytoczonej relacji nabiera podwójnego znaczenia - niektórzy Żydzi powracający z cmentarza w sensie dosłownym zdołali wyjść z grobu. Miśko jednak należał prawdopodobnie do grupy osób, które dzięki zaświadczeniom o pracy ocaliły wtedy życie ${ }^{13}$. Miśko musiał widzieć te dantejskie sceny rozgrywające się na cmentarzu, przypuszczalnie opowiadał też o nich Fryderyce, która jednak w dzienniku nie podaje żadnych szczegółów.

Rozbieżność dat pojawia się w odniesieniu do czasu utworzenia getta. Informacje o planach zorganizowania getta docierają do Fryderyki 3 X 1941 r. Miesiąc później pisze o tym, że w mieście pojawiły się ogłoszenia, iż żydowska dzielnica (Fryderyka pisze: Judische Fürtel) ma powstać do 20 XI 1941 r. Od 15 XI do 17 XI rodzina Brücków szuka mieszkania na terenie getta. 21 XI zarówno ona, jak i rodzina jej chłopaka mieszkają już w getcie. Natomiast według opracowań getto zo-

\footnotetext{
${ }^{12}$ Op. cit.

${ }^{13}$ Por. http://www.jewishgen.org/yizkor/pinkas_poland/pol2_00368.html\#part4.
} 


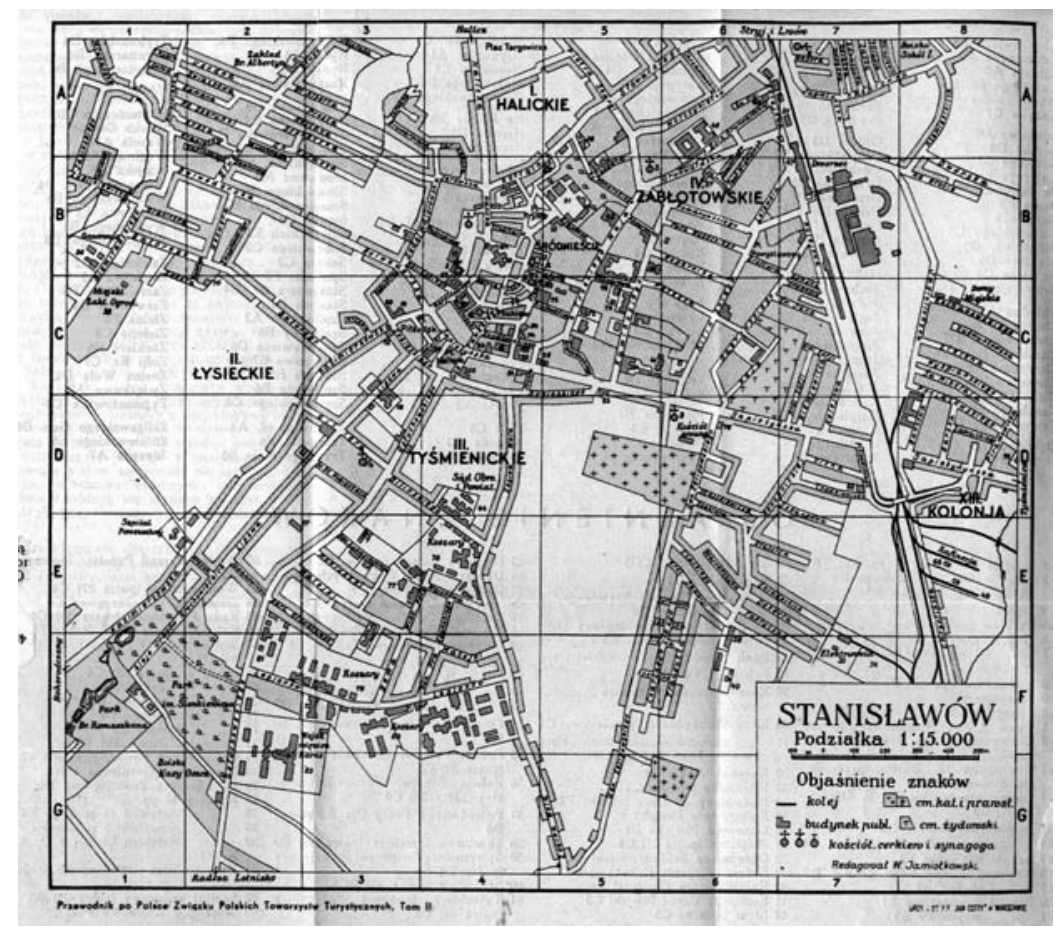

Plan Stanisławowa. Źródło: Przewodnik po Polsce w 4 tomach, Zwiazek Polskich Towarzystw Turystycznych, Tom II: Polska potudniowo-wschodnia, Warszawa 1937

stało zamknięte miesiąc później - ok. 20 XII. We wspomnieniach innych osób też znajdujemy rozbieżności, np. Czesław Herman zeznawał, że getto w Stanisławowie utworzone zostało w październiku $1941 \mathrm{r}^{14}$

Kolejnym dramatycznym zwrotem w życiu Fryderyki są zdarzenia z 31 III 1942, kiedy cała jej rodzina zostaje zabrana i - podobnie jak około 5 tys. innych Żydów wywieziona do obozu w Bełżcu. Fryderyka nie wyobraża sobie istnienia obozów zagłady. Wie o obozach pracy i wspomina o wywózkach do nich na kartach swego dziennika. Między innymi, kiedy denerwuje ją dąsanie się Miśka w czasie, gdy ona załatwia mu zaświadczenie o pracy, stwierdza: „Jestem strasznie na niego zła, jakby to nie pachniało obozem pracy [podkreśl. moje - J. L.], to bym więcej do tego palca nie przyłożyła, ale ponieważ to sprawa bardzo ważna muszę zagryźć wargi i przemilczeć jeszcze ten raz" (15 IX 1941).

Fryderyka nie pisze w swym dzienniku o głodzie, nie przedstawia scen okrucieństwa wobec Żydów rozgrywających się na ulicach Stanisławowa. Wspomina ogólnie o łapaniu ludzi na ulicach i o strachu przed wyjściem z domu. „Bardzo niespokojnie w mieście. Łapią na ulicach. W ogromnym strachu idę do pracy. Potem ni-

\footnotetext{
${ }^{14}$ Op. cit.
} 
gdzie nie wychodzę" (9 X 1941). Nie uskarża się na sprawy materialne i pogorszenie bytu. Jedynie w przytoczonych przez nią słowach Miśka znajdujemy uwagę o tym, że np. nie jest możliwe kupienie dla niej pierścionka: „Powiedział mi, że chciał mi na urodziny kupić pierścionek, ale $\mathrm{z}$ tego powodu, że nie można teraz, to dostanę już zaręczynowy” (10 IX 1941), w innym miejscu Miśko mówi, że „wszystko mu się kończy w domu" (16 III 1942). O wycieńczeniu fizycznym dowiadujemy się z jej dziennika jakby mimochodem, gdy pisze o niemocy seksualnej Miśka: „albo nie ma do mnie pociągu płciowego, albo to dowód wymęczenia fizycznego" (3 III VII 1942). Co więcej - nie ma w jej zapiskach śladu złości na Niemców czy nienawiści do nich. Zasadniczo odróżnia to jej dziennik od literatury wspomnieniowej.

Jak, w świetle znanych dziś wydarzeń historycznych, mogły potoczyć się dalsze losy Fryderyki, niezapisane już w dzienniku? Ostatni wpis dokonany został 1 VIII 1942 r. Według relacji Joachima Nachbara ${ }^{15}$ - 23 VIII 1942, według innych na początku sierpnia ${ }^{16}$, miała miejsce okrutna akcja, w wyniku której wymordowano i pogrzebano w zbiorowej mogile na ulicy Belwederskiej ok. tysiąca Żydów, a członków Judenratu powieszono na lampach i balkonach getta. Pretekstem do tej masakry było oblanie policjanta ukraińskiego ${ }^{17}$ kwasem przez żydowskiego rzemieślnika, u którego ów policjant wykrył kilogram szmuglowanej mąki. Żyd został zastrzelony na miejscu, a Judenratowi wydano polecenie, aby w ciągu trzech dni dostarczyć tysiąc Żydów. Rada Żydowska odmówiła spełnienia rozkazu, dlatego urządzono pokazową egzekucję trzydziestu członków Judenratu, otwierając wyjątkowo bramy getta dla ludności mieszkającej po aryjskiej stronie i wręcz zaganiając ją, aby oglądała to widowisko. Czy Fryderyka zginęła w tej masakrze? Możliwe. Czy może w następnej, która miała miejsce 12 IX 1942 r., kiedy ok. tysiąca martwych ciał leżało na ulicach getta, a kolejnych 5 tys. Żydów wywieziono do Bełżca?

Nie jest też wykluczone, że Fryderyka Brück przerwała pisanie dziennika. Zanim dokonała ostatniego wpisu, nie zanotowała nic przez cztery miesiące, co wyraźnie miało związek z traumatycznym przeżyciem, jakim było zabranie przez Niemców całej jej rodziny. Może zatem forma intymnych zwierzeń na stronach zeszyciku w tak odmienionej rzeczywistości, w obliczu grozy sukcesywnej likwidacji społeczności żydowskiej w Stanisławowie - w końcu przestała być adekwatna.

Ci, którzy przechowali dziennik, zaświadczają, że Fryderyka Brück zginęła.

\section{Dziennik „przeciętnej” nastolatki}

Opisywany tu dziennik jest więc przede wszystkim zapisem intymnych przeżyć, czynionym bez zamiaru udostępniania go osobom trzecim. Fryderyka nie troszczy się o ewentualnego przyszłego czytelnika: nie przedstawia osób, nie wyjaśnia kon-

${ }^{15} \mathrm{Http}: / /$ www.jewishgen.org/yizkor/pinkas_poland/pol2_00368.html\#part4.

${ }^{16} \mathrm{Http}: / /$ stanislawow.net/wspomnienia/herman_droga.htm,

17 Policję ukraińską, Hilfpolizei, utworzono w Stanisławowie w sierpniu 1941 r.; liczyła ona ok. dwustu osób. 
tekstu wydarzeń, wewnątrztekstowy odbiorca jej dziennika posiada wiedzę taką jak ona, zna pojawiające się postaci i ich wzajemne relacje. Autorka - w przeciwieństwie do Anny Frank - nie traktuje też siebie jako osoby szczególnie uzdolnionej literacko, której dziennik kiedyś będzie odkryty i opublikowany. Nie poszukuje jakiejś ambitnej formy literackiej, nie cyzeluje stylu, nie inspiruje się lekturami. Nie zastanawia się nad rangą opisywanych wydarzeń. Wydaje się, że nie stosuje żadnej autocenzury. Szczerze przelewa na papier swoje wrażenia bez szczególnej troski o kreowanie swego wewnątrztekstowego wizerunku. Zdarzenia, które przedstawia, umieszcza w perspektywie osobistego doświadczenia. W ocenie znaczenia sytuacji, których jest świadkiem i uczestnikiem, nie odwołuje się do pamięci zbiorowej ani do procesów historycznych, a jeśli podkreśla ważkość jakiegoś wydarzenia, to dlatego, że ono „zostanie mi w pamięci do końca życia” (13 X 1941). Można więc powiedzieć, że jest to zwyczajny dziennik „przeciętnej” nastolatki. Ale - za sprawą tragizmu historii - właśnie na tym polega dziś siła jego przekazu. Intymność i swoista naiwność narracji dziennika splata się z grozą historycznych wydarzeń, z nie do końca przez autorkę uświadomionym okrucieństwem Zagłady, które ostatecznie przerwie jej zwierzenia.

\title{
Słowa kluczowe
}

dziennik intymny, kobiety i Zagłada, Stanisławów, getto

\begin{abstract}
The article is an introduction to Fryderyka Brück's diary covering notes from 7 May 1941 to 1 August 1942. The author of the diary came from a highly Polonized, welloff Jewish family living in Stanisławów. Her diary begins when she is only a carefree 19-year-old student with a peaceful life. The situation changes drastically after Germans have occupied the town. Fryderyka describes the first Nazi action conducted on Jews and Poles in Stanisławów when together with other representatives of the intelligentsia her father was arrested. One of the most tragic events reported in the diary is a bloody massacre of Jews in the cemetery when 10,000 Jews were killed on 12 October 1941. The notes cover the times of the move to the ghetto and life in the closed district. The girl describes the moment when on 31 March 1942 the whole of Brück family, except for Fryderyka, was taken and transported to the camp. At that time, there is the longest gap in notes and later - the last hastily and carelessly written entry reporting chaotic events from four months. The main subject of the diary is not historical events but the relationship with Misiek Bachar. Therefore, the diary has the character of intimate notes, not intended to be read by third party. The narrative line is the emotional life, the author's love adventures and sexual experiences. She always presents the events from the perspective of personal experience. Therefore, it might be said that it is an ordinary diary of an "average" teenager but this is what its power of message consists in nowadays. The intimacy and the specific naivety of the diary intertwines with the terror of historical events, not necessarily
\end{abstract}


made conscious but also undoubtedly repressed cruelty of the Holocaust which will ultimately interrupt the author's confessions.

\section{Key words}

intimate diary, women and Holocaust, Stanisławów, ghetto 

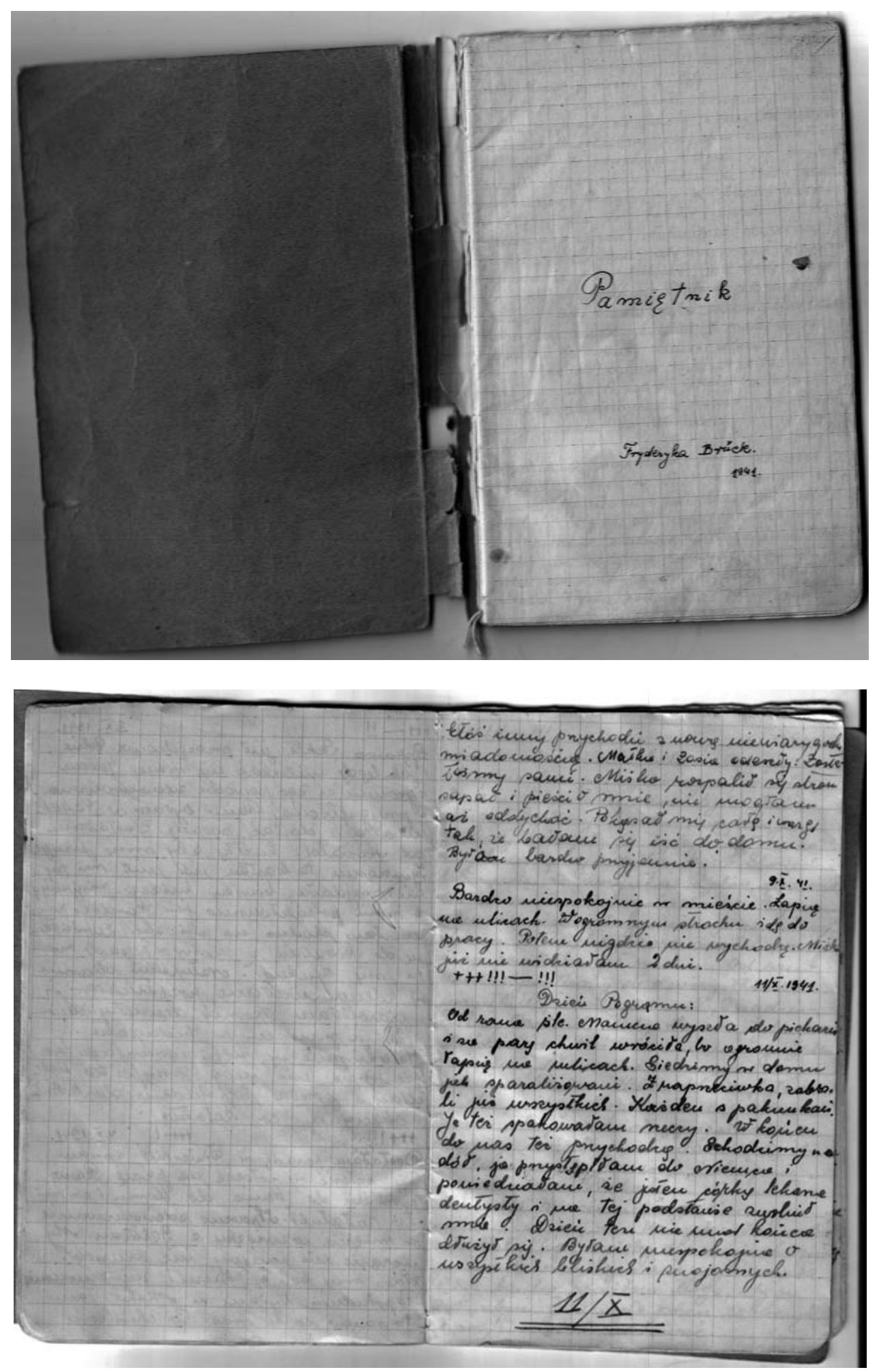

Dziennik Fryderyki Brück 